REV. 2

\title{
LONG-TERM SURVEILLANCE PLAN FOR THE MEXICAN HAT DISPOSAL SITE MEXICAN HAT, UTAH
}

\section{June 1997}

Prepared for

U.S. Department of Energy UMTRA Project Team

Environmental Restoration Division

Albuquerque, New Mexico

Prepared by

Jacobs Engineering Group Inc.

Albuquerque, New Mexico 


\section{DISCLAIMER}

Portions of this document may be illegible in electronic image products. Images are produced from the best available original document. 


\section{TABLE OF CONTENTS}

Section

Page

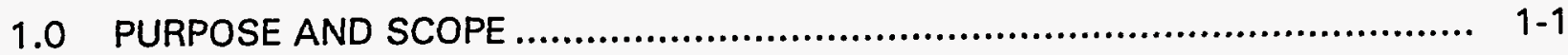

2.0 FINAL SITE CONDITIONS........................................................ $2-1$

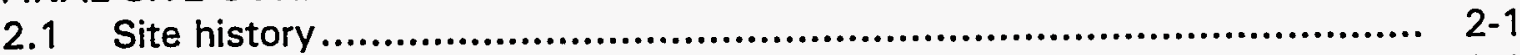

2.2 General description of the site vicinity ........................................ $2-1$

2.3 Disposal site description......................................................... $2-2$

2.3.1 Directions to the disposal site......................................... 2-6

2.3.2 Permanent site-surveillance features ................................. 2-7

3.0 SITE INSPECTIONS .................................................................. $3-1$

3.1 Inspection frequency ....................................................... $3-1$

3.2 Inspection team .............................................................. $3-1$

3.3 Site inspection procedures ................................................... $3-1$

F.4 Follow-up inspections ..................................................... $3-4$

4.0 GROUND WATER................................................................. $4-1$

4.1 Ground water characterization ............................................... 4-1

4.1.1 Hydrostratigraphy....................................................... 4-1

4.1.2 Background ground water quality.................................... 4-5

4.2 Ground water monitoring..................................................... $4-7$

4.3 Cell performance monitoring ................................................. $4-8$

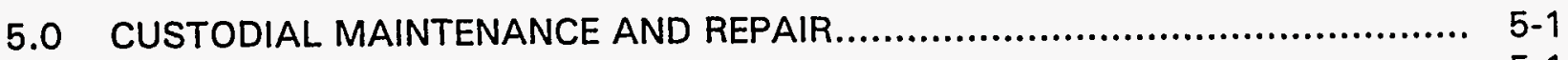

5.1 Planned maintenance .......................................................... $5-1$

5.2 Unscheduled maintenance or repair ............................................ $5-1$

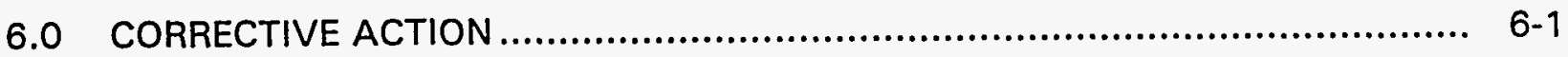

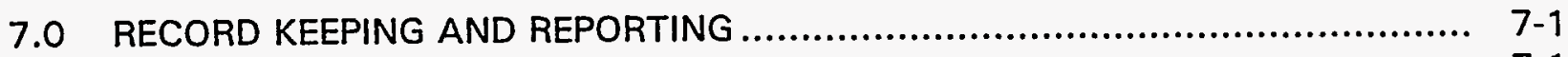

7.1 Permanent site file........................................................... $7-1$

7.2 Inspection reports/annual reports .......................................... $7-1$

8.0 QUALITY ASSURANCE............................................................ $8-1$

8.1 Inspections ..................................................................... $8-1$

8.2 Data validation and quality assurance ...................................... $8-1$

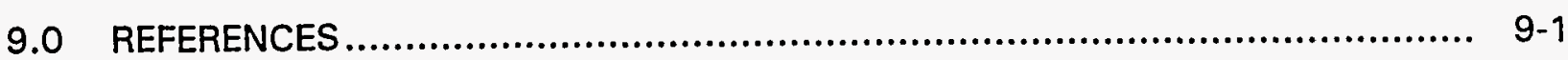

ATTACHMENT 1 NRC CONCURRENCE AND LICENSING DOCUMENTATION

ATTACHMENT 2 LEGAL DESCRIPTION

ATTACHMENT 3 AGENCY NOTIFICATION AGREEMENTS 


\section{LIST OF FIGURES}

Figure

Page

2.1 Disposal site location, Mexican Hat, Utah ............................................. 2-3

2.2 Disposal site vicinity map, Mexican Hat, Utah ......................................... 2-4

2.3 Cross section of disposal cell cover, Mexican Hat, Utah, site ........................ 2-5

3.1 Steps for follow-up inspections, custodial maintenance, and corrective action, Mexican Hat, Utah, disposal site ............................... 3-2

4.1 Typical geologic cross section, Mexican Hat, Utah, disposal site .................... 4-2

4.2 Seep locations at the Mexican Hat, Utah, disposal site............................... 4-4

\section{LIST OF PLATES}

Plate

1 Disposal site map, Mexican Hat, Utah

\section{LIST OF TABLES}

Table

4.1 Background ground water quality for the Halgaito Shale and Honaker Trail Formation, Mexican Hat, Utah, site. 


\section{LIST OF ACRONYMS}

Acronym Definition

DOE

LTSP

NGVD

NRC

QA

RAP

RRM

TDS

UMTRA

UMTRCA
U.S. Department of Energy

long-term surveillance plan

National Geodetic Vertical Datum

U.S. Nuclear Regulatory Commission

quality assurance

remedial action plan

residual radioactive material

total dissolved solids

Uranium Mill Tailings Remedial Action

Uranium Mill Tailings Radiation Control Act 
CHANGE HISTORY

\begin{tabular}{lll}
\hline Document version & Date & Pages/comments \\
\hline Rev. 0 & $09 / 1 / 95$ & Initial version. \\
\hline Rev. 1 & $02 / 07 / 96$ & $\begin{array}{l}\text { Client and author review comments } \\
\text { incorporated. Document } \\
\text { transmitted for agency review. }\end{array}$ \\
\hline Rev. 2 & $\begin{array}{l}\text { Reorganized document based on } \\
1996 \text { LTSP Guidance Document. } \\
\text { Incorporated comments from GJO, } \\
\text { Navajo Nation and NRC. }\end{array}$ \\
\hline
\end{tabular}




\subsection{PURPOSE AND SCOPE}

This long-term surveillance plan (LTSP) describes the U.S. Department of Energy's (DOE) long-term care program for the Uranium Mill Tailings Remedial Action (UMTRA) Project Mexican Hat, Utah, disposal site.

The U.S. Nuclear Regulatory Commission (NRC) has developed regulations for the issuance of a general license for the custody and long-term care of UMTRA Project disposal sites in 10 CFR Part 40. The purpose of this general license is to ensure that the UMTRA Project disposal sites will be cared for in a manner that protects the public health and safety and the environment. Before each disposal site is licensed, the NRC requires the DOE to submit a site-specific LTSP. The DOE prepared this LTSP to meet this requirement for the Mexican Hat disposal site. The general license becomes effective when the NRC concurs with the DOE's determination of completion of remedial action for the disposal site and the NRC formally accepts this LTSP.

This LTSP describes the long-term surveillance program the DOE will implement to ensure that the Mexican Hat disposal site performs as designed. The program is based on two distinct types of activities: 1/ site inspections to identify potential threats to disposal cell integrity, and 2) monitoring of selected seeps to observe changes in flow rates and water quality. The LTSP is based on the UMTRA Project long-term surveillance program guidance (DOE, 1996a) and meets the requirements of $10 \mathrm{CFR} \$ 40.27(\mathrm{~b})$ and $40 \mathrm{CFR}$ $\S 192.03$. 


\subsection{FINAL SITE CONDITIONS}

\section{$2.1 \quad$ SITE HISTORY}

The mill at the Mexican Hat site was constructed and operated from 1957 to 1963 by Texas-Zinc Minerals Corporation. Atlas Corporation purchased the mill in 1963, and operated it until it was closed in 1965. The mill was built on land leased from the Navajo Nation; control of the site reverted to the Navajo Nation after the Atlas Corporation lease expired in 1970 (FBDU, 1981). The designated Mexican Hat UMTRA Project site covered 235 acres (ac) (95 hectares [ha]).

Much of the ore processed at the Mexican Hat site came from the White Canyon area of Utah and contained a considerable amount of copper sulfide and other sulfide minerals. The ground ore was treated by froth flotation. The flotation concentrates and tailings were acid-leached separately to recover both copper and uranium products. During its operation, the mill processed 2.2 million tons ( 2.0 million metric tons) of ore and produced 5700 tons (5200 metric tons) of uranium concentrate. In addition to the milling operation, a sulfuric acid manufacturing plant operated at the site until 1970 (FBDU, 1981). At the time of the remedial action, the concrete pad for the mill building and several associated buildings and structures (e.g., scale house, office building, and tanks) remained.

The Monument Valley site is in Apache County, Arizona, and is within the Navajo Nation Reservation approximately 17 road miles (mi) $(27$ kilometers [km]) south of the Mexican Hat site. At the time of remedial action, the 98-ac (40-ha) Monument Valley designated site contained two tailings piles covering approximately 28 ac (11 ha), concrete building foundations, and debris (DOE, 1989). The total volume of residual radioactive material (RRM) at the Monument Valley site, including the tailings, soils beneath and around the tailings, and other contaminated materials, was estimated to be 983,300 yards $(y d)^{3}\left(751,800\right.$ meters $\left.\left[m^{3}\right]\right)$ (DOE, 1989). The Monument Valley site RRM was transported to the Mexican Hat site and placed on top of the Mexican Hat RRM in the disposal cell.

The remedial action at the Mexican Hat disposal site was completed in 1995. Approximately 3.6 million $\mathrm{yd}^{3}\left(2.8\right.$ million $\left.\mathrm{m}^{3}\right)$ of RRM were stabilized in a disposal cell at the location of the lower Mexican Hat tailings pile. The former mill office building and sewage lagoons were left intact. At the completion of surface remedial action, the roughly pentagonal-shaped disposal cell covered approximately 68 ac ( $28 \mathrm{ha})$, and the fenced disposal site encompassed approximately 119 ac (48 ha).

\subsection{GENERAL DESCRIPTION OF THE SITE VICINITY}

The Mexican Hat disposal site is in San Juan County, Utah, in Sections 13 and 24, Township 42 South, Range 18 East, and Sections 18 and 19, Township 42 
South, Range 19 East, Salt Lake Principal Meridian. The site encompasses approximately 119 ac (48 ha) within the Navajo Nation Reservation approximately 2 road mi $(3 \mathrm{~km}$ ) southwest of the town of Mexican Hat, Utah (Figures 2.1 and 2.2). The small Navajo community of Halchita is approximately 0.5 road mi $(0.8 \mathrm{~km})$ southwest of the site. The closest city with commercial airline service is Farmington, New Mexico, approximately 134 road mi $(216 \mathrm{~km}$ ) to the southeast.

The Mexican Hat disposal site is within the Colorado Plateau physiographic province that covers approximately 114,000 square miles $\left(\mathrm{mi}^{2}\right)(296,000$ square kilometers $\left[\mathrm{km}^{2}\right]$ ) in Utah, Arizona, Colorado, and New Mexico. Major topographic features in the area are the deeply entrenched San Juan River to the north and prominent Raplee Ridge to the northeast. The elevation of the site is approximately $4300 \mathrm{ft}(1300 \mathrm{~m})$ above the National Geodetic Vertical Datum (NGVD) of 1929. The climate in the area is arid with widely ranging daily and annual temperatures. Winters are cold (nighttime temperatures below freezing prevail from November through Marchl, and summers are hot with high temperatures from 90 to 100 degrees Fahrenheit $\left({ }^{\circ} \mathrm{F}\right)$ (32 to 37 degrees centigrade $\left.\left[{ }^{\circ} \mathrm{C}\right]\right)$. Prevailing winds are from the southwest. Average annual precipitation is 6 inches $(15 \mathrm{~cm})$. Precipitation is fairly evenly distributed throughout the year. Snowfall is usually light. Mexican Hat received an annual average of 3.3 inches (in) (8.4 centimeters [cm]) of snow from 1951 through 1980. The area is sparsely vegetated by desert shrubs and grasses, and the land around the site is used for limited residential purposes and livestock grazing (DOE, 1987).

\section{$2.3 \quad$ DISPOSAL SITE DESCRIPTION}

Attachment 2 provides a legal description of the site. The final conditions at the Mexican Hat disposal site are shown on Plate 1. The aboveground disposal cell covers approximately 68 ac (28 ha) and contains approximately 4.4 million tons (4.0 million metric tons) of RRM including uranium mill tailings, contaminated soils, and mill site debris (e.g., demolished building materials). The disposal cell abuts a steep ridge to the south and rises to a height of approximately 50 feet (ft) (15 meter [m]) above the surrounding terrain to the north, east, and west.

The Mexican Hat and Monument Valley RRMs were consolidated, compacted, and stabilized at the location of the lower tailings pile at the Mexican Hat site. The sideslopes of the disposal cell were limited to a 20 percent grade to create a stable slope, and the top of the disposal cell has a 2 percent grade to promote drainage. The cover placed over the disposal cell has three components, as shown in Figure 2.3. The RRM was encapsulated with a radon barrier composed of fine-grained material, the purpose of which is to control radon 

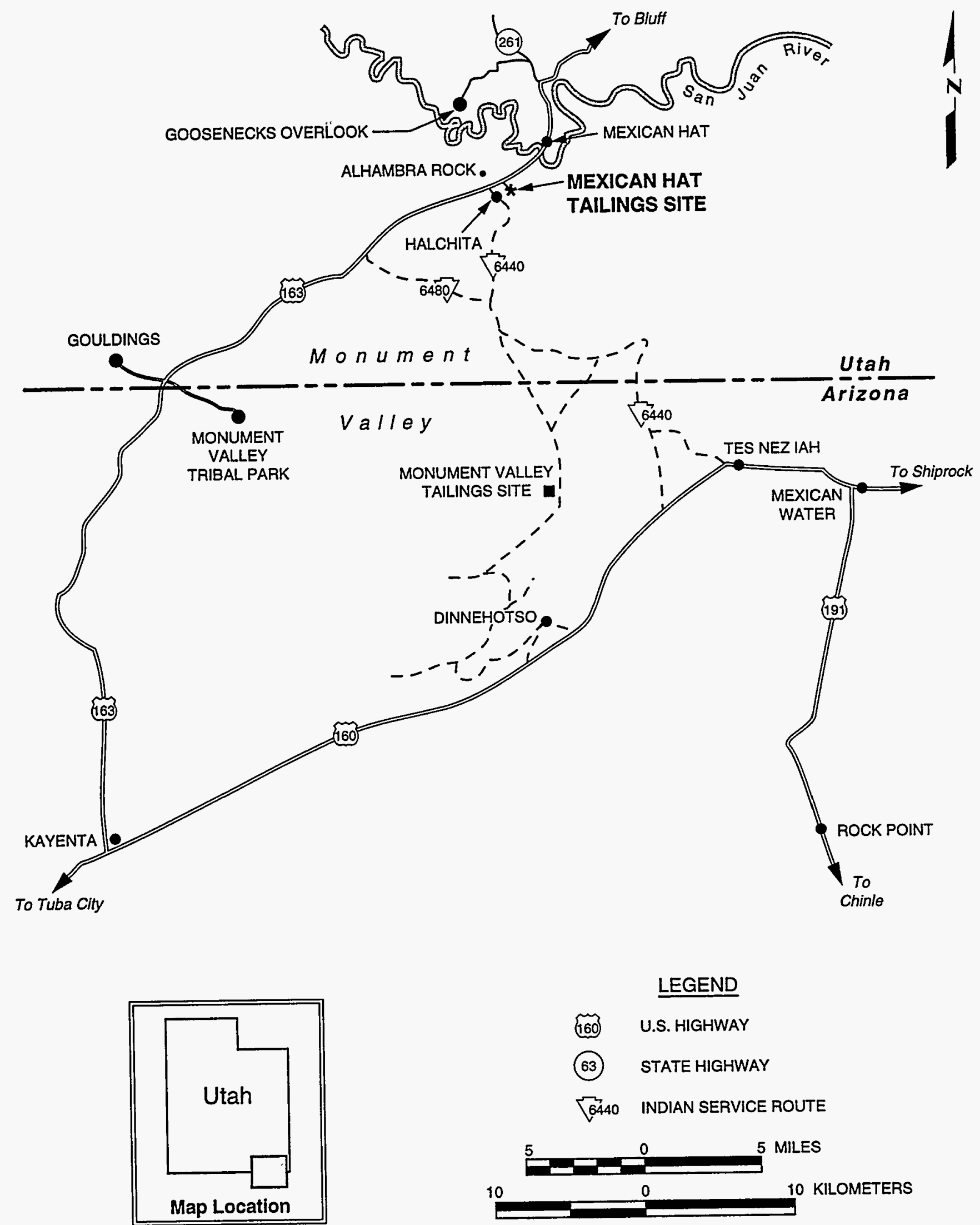

FIGURE 2.1

DISPOSAL SITE LOCATION

MEXICAN HAT, UTAH 


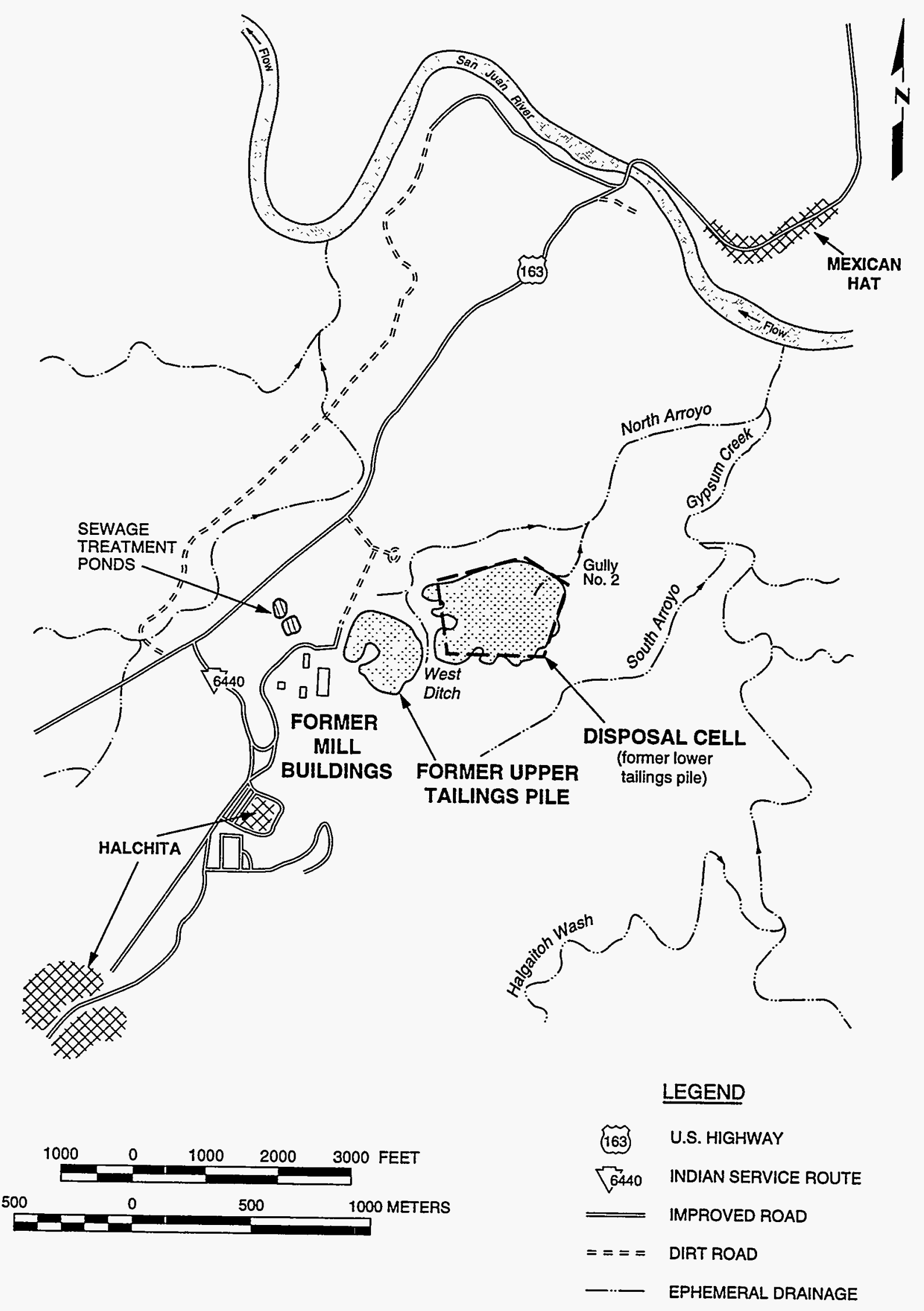

FIGURE 2.2

DISPOSAL SITE VICINITY MAP MEXICAN HAT, UTAH 


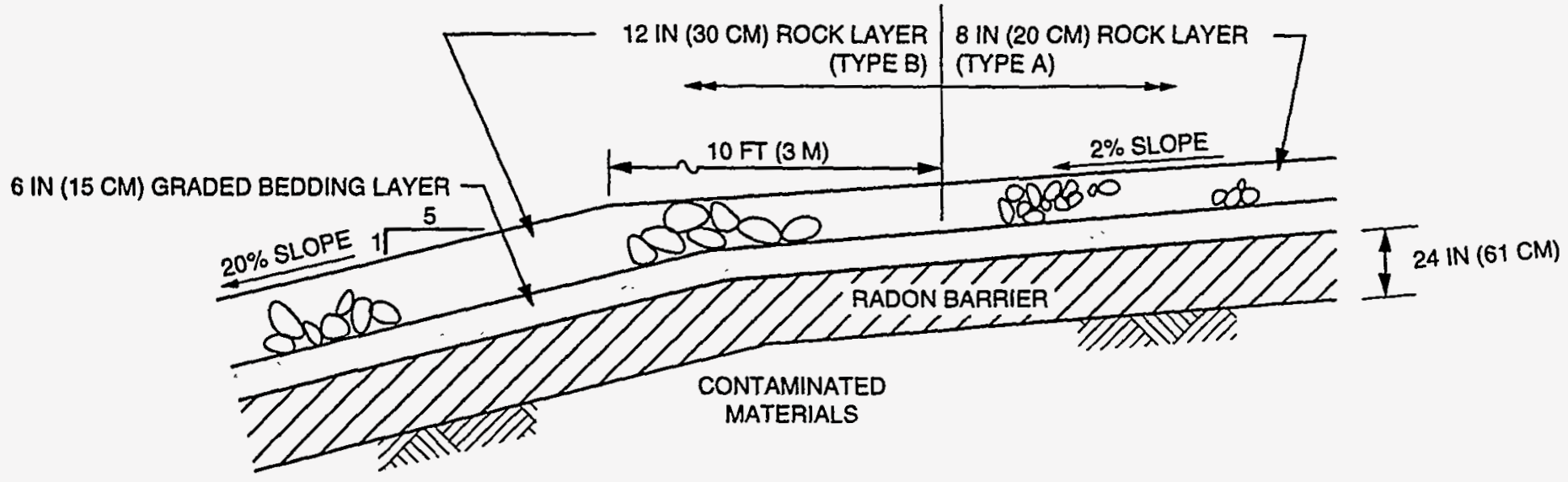

SCHEMATIC - NOT TO SCALE

FROM MK-F, 1995.

FIGURE 2.3

CROSS SECTION OF DISPOSAL CELL COVER

MEXICAN HAT, UTAH, SITE 
emanation and water infiltration. The radon barrier consists of 24 inches 161 $\mathrm{cm}$ ) of compacted silty sand amended with 10 percent bentonite clay. The radon barrier is covered with a 6 -inch $(15-\mathrm{cm})$-thick graded bedding layer of coarse sand and gravel. The graded bedding layer protects the fine-grained radon barrier during placement of the rock layers and functions as a drain that sheds water laterally off the disposal cell while protecting the radon barrier from erosion caused by interstitial flow. The graded bedding layer was covered with a layer of coarser-grained material to prevent erosion due to wind or rain. The erosion protection layer consists of an 8-inch $(20-\mathrm{cm})$-thick layer of 1.7-inch $(4.3-\mathrm{cm})$ or larger mean diameter rock (riprap) on the top of the disposal cell and a 12 -inch $(30-\mathrm{cm})$-thick layer of 4.4 -inch $(11-\mathrm{cm})$ or larger mean diameter rock on the sideslopes and aprons of the disposal cell.

The Mexican Hat disposal cell and a portion of the surrounding area were graded and permanent drainage features were constructed to minimize erosion (Plate 1). Runoff from the western watershed at the site and the western sideslope of the disposal cell will be intercepted by the west ditch and channeled into the North Arroyo. The southwest ditch will direct runoff from the watershed southwest of the disposal cell into the west ditch. Runoff from the eastern sideslopes of the disposal cell will flow eastward and northeastward as sheet flow and be released across the rock-covered aprons at the base of the cell. Runoff from the top of the disposal cell will flow to the north, and northeast as sheet flow and then down the northern sideslope across the rock-covered apron into the north ditch and into the North Arroyo. The west, north, and diversion ditches are sized to carry the runoff from 1-hour rainfall intensity of a probable maximum precipitation event and are excavated into an erosion-resistant layer of sandstone and lined with engineered rockfill (riprap). The north ditch also has an excavated keyway with riprap at its outfall into the North Arroyo to prevent headcutting, and three gullies on the northern and eastern sides of the disposal cell are armored with riprap (i.e., north, northeast, and east apron toe drains) to prevent advancement toward the cell. There is also a drainage channel approximately $150 \mathrm{ft}(46 \mathrm{~m})$ long at the southeast corner of the base of the disposal cell. This drainage channel is lined with riprap and drains into the South Arroyo.

The surface conditions of the Mexican Hat disposal site will be monitored during the annual or scheduled inspections to determine whether the disposal cell and associated erosion protection measures are performing as intended. The general guidelines to be followed during these site inspections are presented in Section 3.0.

\subsubsection{Directions to the disposal site}

To reach the Mexican Hat disposal site, follow these directions:

- Proceed approximately $1.2 \mathrm{mi}(2 \mathrm{~km})$ southwest on U.S. Highway 163 from the north end of the U.S. Highway 163 bridge over the San Juan River (Figure 2.2). 
- Turn left (southeast) onto a gravel road which will immediately pass under power transmission lines.

- Take the left fork at the "Y" intersection at the top of the hill, and stay to the left to descend to the level parking area at the northwest corner of the disposal site.

The distance from U.S. Highway 163 to the parking lot is approximately $0.2 \mathrm{mi}$ $(0.3 \mathrm{~km})$. The entrance gate is near the northwest corner of the disposal cell.

\subsubsection{Permanent site-surveillance features}

The Mexican Hat disposal site is completely enclosed with a barbed wire fence. Access to the disposal site is provided by a locked, double-leaf swing gate at the northwest corner of the disposal site.

One entrance sign and 43 perimeter signs are at the Mexican Hat disposal site (Plate 1). These signs provide information about the purpose of the site. Two granite site markers at the disposal site also provide information about the site: one marker is at the disposal site entrance, and the other marker is on the crest of the disposal cell (Plate 1).

The DOE and Navajo Nation 24-hour emergency telephone numbers on the entrance sign and agreements with local agencies to notify the DOE in the event of an emergency or breach of site integrity will provide additional security measures. Because of the remote location of the disposal site, deliberate intrusion is unlikely. However, if intrusion, vandalism, or grazing is identified during site inspections, site security will be reevaluated. 


\subsection{SITE INSPECTIONS}

The DOE will conduct routine inspections of the Mexican Hat disposal site to detect progressive changes caused by slow-acting natural processes and to identify potential problems before the need for extensive maintenance, repairs, or corrective action. Inspections may also be performed if DOE receives information regarding events or conditions that could potentially affect the disposal site. The DOE will compare the findings from these inspections to initial baseline conditions to identify changes over time and to provide a basis for future inspections, repairs, and corrective actions. This process is shown in Figure 3.1. Custodial maintenance and repair are described in Section 5.0. Corrective action is detailed in Section 6.0.

\section{$3.1 \quad$ INSPECTION FREQUENCY}

The DOE will inspect the Mexican Hat disposal site annually, preferably during the volunteer plant growing season. The DOE may schedule more frequent inspections at any time should the need arise. The DOE will notify the NRC and Navajo Nation of the inspection schedule.

Seep monitoring will be scheduled independent of annual inspections, if necessary, to ensure that seeps and vegetation are monitored during appropriate seasons.

\subsection{INSPECTION TEAM}

The inspection team will consist of a minimum of two inspectors qualified to inspect disposal cell integrity and make preliminary assessments of modifying processes that could adversely affect the disposal cell.

If problems are observed that require more investigation, follow-up inspections will be performed and will include one or more technical specialists in appropriate disciplines to assess the problems under investigation.

\subsection{SITE INSPECTION PROCEDURES}

Before each inspection, inspectors will perform a preinspection briefing. The long-term surveillance program guidance document contains information useful in preparing for inspections (DOE, 1996a).

Site inspections will cover the disposal cell, the surrounding disposal site area, and the immediate off-site areas. Additionally, preselected seeps within a half-mile radius and downslope will be monitored. Site inspections must be thorough enough to identify significant changes or active modifying processes that could potentially adversely affect the disposal cell. Surveillance should be performed to identify unanticipated effects of modifying processes such as gully formation, slope erosion, changes to the rock cover, ephemeral 


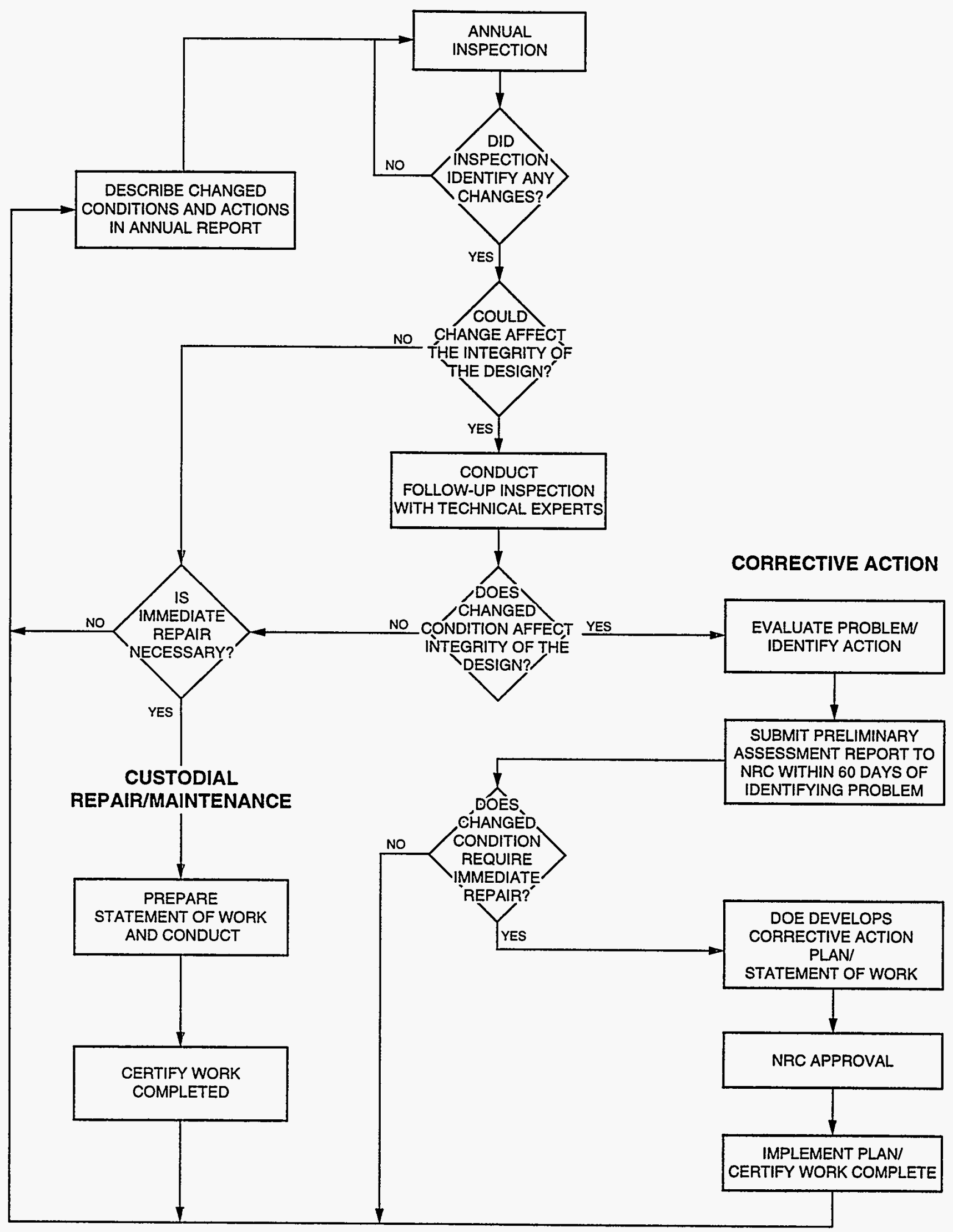

FIGURE 3.1

STEPS FOR FOLLOW-UP INSPECTIONS, CUSTODIAL MAINTENANCE, AND CORRECTIVE ACTION MEXICAN HAT, UTAH, DISPOSAL SITE 
drainage channel changes, and significant modifications by humans, animals, or plants.

Processes anticipated in the disposal cell design that should not cause undue concern during inspections are:

- Minor gullying and headward erosion of arroyos in the site area. This will not impact cell performance (e.g., erosion protection by the rock sideslopes and aprons). Engineering geology studies evaluated the geomorphic stability of the disposal cell and determined that minor gullying is to be expected but erosion resistant bedrock in the site area will prevent headcutting that would adversely affect the disposal cell (MK, 1992).

- Weathering/dislocation of large-diameter rock placed in the North Arroyo. Large boulders from excavation and cleanup of the disposal site area were placed in the North Arroyo adjacent to gully \#1. This was done as a "best management practice" and their long-term stability is not critical to the disposal cell performance.

Inspectors will evaluate the integrity of the disposal cell by walking a series of transects around the perimeter and over the rock cover. Sufficient transects, at approximately $150-\mathrm{ft}(46-\mathrm{m})$ intervals, must be walked so that the disposal cell is thoroughly covered and inspected. Diagonal transects of the topslope will be made. Additional transects will be walked along the sideslopes and rock apron. Transects along the entire length of the ditches will be made to determine whether it is functioning as designed and can be expected to continue to function properly. Inspectors will review transect paths from previous inspections and make efforts to vary the path of transects from one inspection to the next to ensure small anomalies are not overlooked. The sample inspection checklist lists items that should be examined during inspections (DOE, 1996a).

Site inspections also will monitor damage to or disturbance of permanent sitesurveillance features, ground water monitor wells, fencing, gate, and locks.

From inside the disposal site, inspectors will visually survey the area within a maximum of $0.25 \mathrm{mi}(0.40 \mathrm{~km})$ from the site property boundary for evidence of land-use changes that indicate increased human activity such as land development or new roads and paths. Inspectors will note the condition of and changes to site access roads, surrounding vegetation, and relevant geomorphic features like gullies or ephemeral drainage channels; potential impacts to the site will be noted. Off-site DOE monitor wells not needed for the Ground Water Program will be abandoned. 


\section{Features to be photographed}

The following site features should be documented by photographs during every scheduled inspection at the Mexican Hat disposal site:

- Survey and boundary monuments, site markers, and entrance and perimeter signs.

- Fencing and entrance gate.

- The disposal cell (crest, sideslopes, aprons, and surrounding area). Panoramic sequences of photographs from selected vantage points may be used for this purpose.

- Disposal cell sideslopes and changes along the grade between the topslopes and sideslopes.

- Drainage, ditches, and armored gullies.

- Off-site features (including seeps) that the inspector deems significant and that may affect the disposal site in the future.

- Volunteer vegetation on the disposal cell and any other vegetation that may affect the integrity of the disposal site.

- Eolian deposition or erosion.

- Any other evidence of erosion the inspector deems significant (e.g., gullies or rills).

- Erosion protection material (riprap).

\subsection{FOLLOW-UP INSPECTIONS}

In addition to annual inspections, the DOE may conduct follow-up inspections due to unusual or annual inspection results. The DOE will monitor the area of the disposal cell for the occurrence of extreme natural events le.g., earthquakes, tornadoes, floods) and vandalism to ensure such events are investigated in a timely manner so as to assess their effects on the disposal cell. To facilitate this, the DOE has requested notification from federal and local agencies of discoveries or reports of purposeful intrusion or damage at the disposal site as well as in the disposal site area. Notification agreements with the San Juan County Sheriff's Office and the U.S. Geological Survey's National Earthquake Information Center are included in Attachment 3. The DOE will also monitor the weather for the occurrence of severe storms in the vicinity of the disposal cell. In addition, the DOE 24-hour telephone number is posted on the site entrance sign so the public can notify the DOE if problems are discovered. If an extreme natural event or vandalism has occurred, the site will be inspected 
to assess the damage. The notification, response, and all follow-up activities will be documented. This documentation will be included in the annual site report to the NRC and become part of the permanent site file.

The nature of the occurrence and the amount of firsthand knowledge available will determine the DOE's response. If a situation poses a threat to the public, the DOE will notify individuals who may be affected and appropriate federal, state, and local agencies, including the NRC. If necessary, the DOE will schedule a follow-up inspection to assess potential effects from the unusual occurrence, and will take necessary response action. DOE may conduct followup inspections to investigate and quantify specific problems found during a previous inspection, other DOE-initiated activity, or other confirmed reports of vandalism, intrusion, damage, unusual occurrences, or other significant threat to the disposal site. Follow-up inspections will be conducted to determine whether processes currently active at or near the site threaten site security or stability and to evaluate the need for custodial maintenance, repair, or other corrective action. The scope of these follow-up inspections may be broad and similar in nature to routine site inspections or focused on specific areas of concern.

A follow-up inspection usually will begin with an on-site visit by technical specialists to further investigate the reported problem and determine if the disposal cell has been damaged or to determine the need for more definitive tests or studies. The DOE will schedule additional site visits if more data are needed to draw conclusions and to recommend repairs or corrective action. 


\subsection{GROUND WATER}

\subsection{GROUND WATER CHARACTERIZATION}

Hydrogeologic conditions at the disposal site are summarized below and are described in detail in the remedial action plan (RAP) (DOE, 1993), and in the NRC's technical evaluation report (NRC, 1996).

\subsubsection{Hydrostratigraphy}

The Mexican Hat disposal site is approximately $1 \mathrm{mi}(1.6 \mathrm{~km})$ south of the San Juan River on a relatively flat mesa at an elevation of approximately $4300 \mathrm{ft}$ $(1300 \mathrm{~m})$ above mean sea level. Surface drainage from the site and surrounding area is to the San Juan River. Bounding the relatively flat mesa to the north and east are the ephemeral drainages North Arroyo and Gypsum Creek. These drainages are relatively narrow and deeply incised. The terrain west of the site is similar to that to the north and east (DOE, 1995; 1993). A ridge that extends approximately $100 \mathrm{ft}(30 \mathrm{~m})$ above the site bounds the site on the south.

The Halgaito Shale, the lowermost unit of the Permian Cutler Group, is exposed at the ground surface of the site (Figure 4.1). This shale consists primarily of interbedded silty sandstone, siltstone, and shale. Calcareous, well cemented beds alternate with less-cemented beds, and there are some thin lenticular beds of limestone and conglomerate (siltstone and limestone pebbles in a silty matrix). The unit is 80 to $215 \mathrm{ft}(24$ to $66 \mathrm{~m})$ thick in the site vicinity. Two sets of nearly vertical fractures trending east-west and northeast-southwest and fractures along bedding planes that dip toward the east are present in the upper portion of the Halgaito Shale at the site. The presence and size of the fractures decreases significantly with depth (DOE, 1995; 1993).

The Honaker Trail Formation is the uppermost unit of the Hermosa Group and lies beneath the Halgaito Shale (Figure 4.1). The Honaker Trail Formation consists of interbedded siltstone, limestone, shale, and sandstone. Chert and limestone nodules are found throughout the siltstone beds, and the limestone units are predominantly fine to very fine grained. The formation is more than $300 \mathrm{ft}(90 \mathrm{~m})$ thick (DOE, 1995; 1993).

The Halgaito Shale was unsaturated before the uranium processing activities at the Mexican Hat site. Nearly all of the ground water presently contained in the Halgaito Shale is a result of the former uranium processing operations (the discharge of process water and water used to place the tailings) and, to a lesser degree, transient drainage from the disposal cell. The ground water in the shale is contained primarily in fractures and is perched on underlying zones having a lower hydraulic conductivity. The unit exhibits very little primary hydraulic conductivity due to the fine-grained nature of the sediments and intergranular 


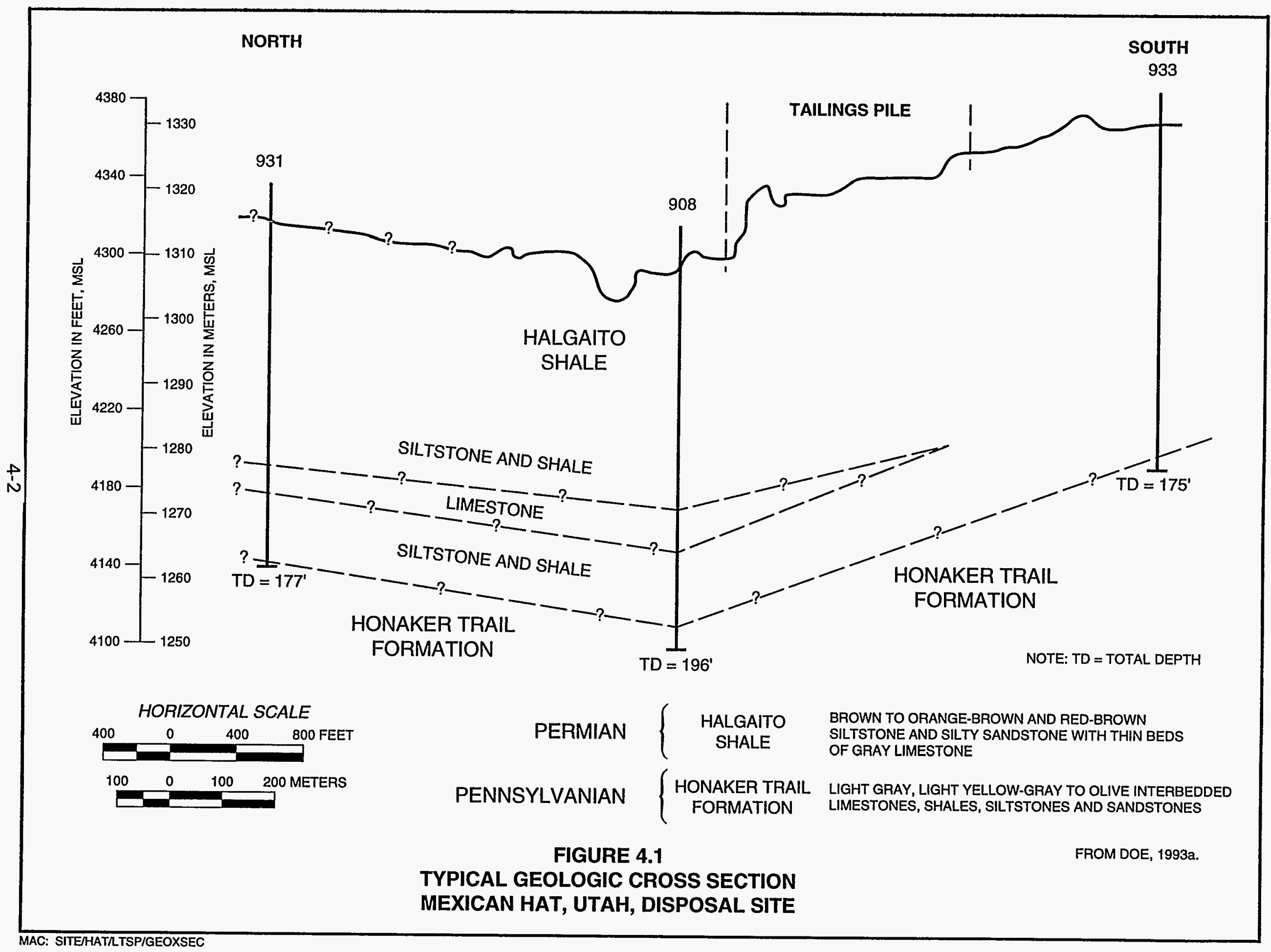


cements. The hydraulic conductivity of the unit decreases with depth because of the decrease in the number and size of the fractures, and the lower portion of the unit is a very effective confining layer that significantly limits the vertical exchange of ground water between the Halgaito Shale and the underlying Honaker Trail Formation (DOE, 1995; 1993).

Recharge to the Halgaito Shale is limited by low annual precipitation 6 inches $[15 \mathrm{~cm}]$ per year) and high evaporation. Discharge is through the fractures and on low-permeability beds as the ground water travels toward seeps in the North Arroyo and Gypsum Creek. Some recharge does occur as evidenced by an uncontaminated seep from the shale in Gypsum Creek. The ground water in the Halgaito Shale that is affected by the disposal site is limited in areal extent and yield and has no current use as a water resource (DOE, 1995; 1993).

The Honaker Trail Formation contains an aquifer below the Halgaito Shale. The aquifer is isolated from ground water in the Halgaito Shale because the lower portion of the Halgaito Shale is a very effective confining layer and an upward hydraulic gradient in the Honaker Trail Formation prevents ground water in the Halgaito Shale from entering the Honaker Trail Formation (DOE, 1995). Water levels in the confined Honaker Trail aquifer are above the perched water levels in the Halgaito Shale and above the ground surface in some locations, including at the disposal site. Ground water in the Honaker Trail aquifer flows northeast toward the San Juan River, which is the discharge area for the aquifer.

Recharge to the aquifer is limited and may occur as precipitation in areas to the southwest where the formation is closer to or exposed at the ground surface. Recharge may also occur as upward flow from deeper units. The ground water in the Honaker Trail Formation is not contaminated from the uranium processing activities, but its natural quality in the vicinity of the Mexican Hat disposal site likely is unsuitable for consumption. Monitor wells at the disposal site showed the presence of hydrogen sulfide gas and naturally occurring petroleum. The Halgaito Shale and Honaker Trail Formation produced a limited amount of oil in the oil field near the town of Mexican Hat (DOE, 1995; 1993).

Three seeps $(251,249$, and 255$)$ have been identified in or near the North Arroyo in the vicinity of the Mexican Hat disposal site (Figure 4.2). Seep 251 was first noticed in December 1989 during the relocation of the upper tailings pile to the lower tailings pile; however, dense green vegetation in aerial photographs taken as early as 1974 show evidence of the earlier occurrence of near surface water at this location. The flow rate at seep 251 was measured in February 1990 at 4 gallons (gal) (15 liters [L]) per hour, but the flow decreased until it stopped in May 1990. The seep was observed to flow again during remedial action in May 1994. It is not possible to predict when the intermittent flow from seep 251 will stop (DOE, 1995; 1993). 


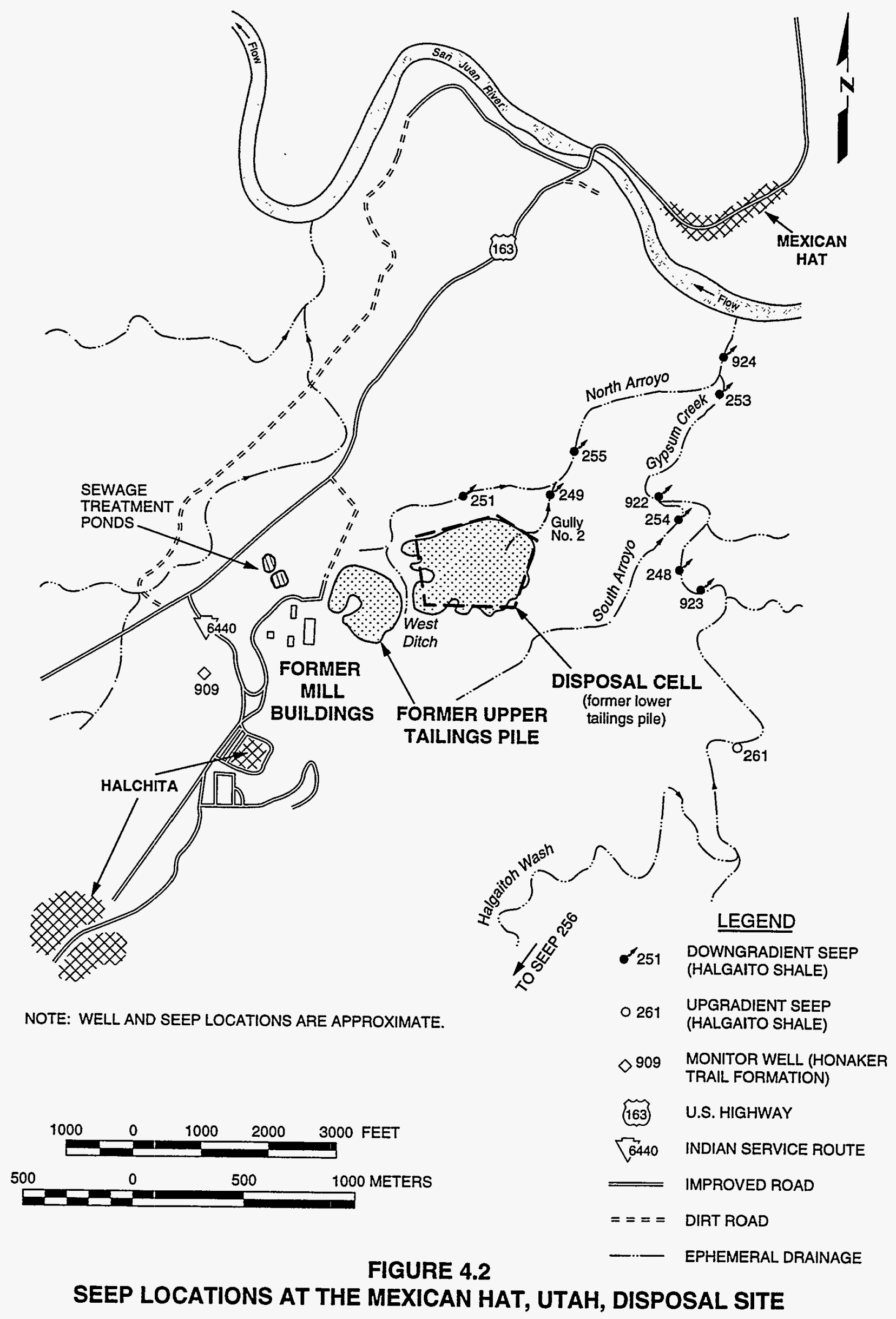


Flow rates at seep 249 (Figure 4.2) were $0.5 \mathrm{gal}(1.9 \mathrm{~L})$ per hour in March 1990 and $0.35 \mathrm{gal}(1.3 \mathrm{~L}$ ) per hour in July 1990 (DOE, 1995; 1993). A spring in this area was documented in 1968 (Snelling, 1971), and there is no record that the seep has stopped flowing since the relocation of the upper tailings pile to the lower tailings pile. The seep was observed to flow during remedial action in May 1994. Insufficient information is available to accurately predict the continuation of seepage at this location (DOE, 1995; 1993).

Flowing water has been observed at seep 255 as far back as March 1976 (DOE, 1990), and the seep was observed from 1988 through 1990 by UMTRA Project personnel. The seep was observed to flow during remedial action in May 1994. No flow rates have been measured at seep 255, and it is not possible to predict when the seep will stop flowing (DOE, 1995; 1993).

Seven seeps $(261,923,248,254,922,253$, and 924) have been identified in the Gypsum Creek drainage in the vicinity of the Mexican Hat disposal site (Figure 4.2). Flow rates from these seeps have not been determined, however, the seeps do not have continuous flows of water (DOE, 1995; 1994; 1993).

\subsubsection{Background ground water quality}

Background ground water quality was determined for the Halgaito Shale and underlying Honaker Trail Formation at the Mexican Hat disposal site. The Halgaito Shale contains only minor amounts of naturally occurring water, and upgradient monitor wells in the shale were dry. Therefore, background ground water quality for the Halgaito Shale was determined using seep 256 in Halgaitoh Wash and seep 261 in Gypsum Creek upgradient of the disposal site (Figure 4.2). The water quality of these seeps is very similar, and both seeps appear to be isolated from ground water contamination related to the disposal site. Background ground water quality for the Honaker Trail Formation was determined using monitor well 909 upgradient of the disposal site (Figure 4.2) (DOE, 1995; 1993).

The background ground water quality of the Halgaito Shale and Honaker Trail Formation is generally similar because both units are lithologically similar (Table 4.1). Both units contain the same calcium sulfate as the mineral gypsum, which has been positively identified in outcrops of the Halgaito Shale. This is reflected in the background ground water quality. Ground waters from both units contain relatively high concentrations of sulfate as the dominant anion (2000 to 3300 milligrams per liter [mg/L]) balanced by nearly equal equivalents of sodium, calcium, and magnesium. The $\mathrm{pH}$ of the ground waters is slightly alkaline, and the ground waters in both units are oxidizing. Total dissolved solids (TDS) in the ground waters range from 3200 to $5300 \mathrm{mg} / \mathrm{L}$ (DOE, 1995; 1993). 
Table 4.1 Background ground water quality for the Halgaito Shale and Honaker Trail Formation, Mexican Hat, Utah, site

\begin{tabular}{|c|c|c|}
\hline Constituent & Halgaito Shale $^{a}$ & Honaker Trail Formation $^{b}$ \\
\hline Alkalinity & $189-289$ & $133-159$ \\
\hline Aluminum & $<0.05$ & $<0.1-0.3$ \\
\hline Ammonium & $<0.01-0.5$ & $<0.1-0.4$ \\
\hline Antimony & $<0.02$ & $<0.003-0.006$ \\
\hline Arsenic & $<0.01$ & $<0.01-0.02$ \\
\hline Barium & $<0.002-0.02$ & $<0.01-0.1$ \\
\hline Beryllium & $<0.005$ & \\
\hline Boron & $0.3-0.4$ & $0.1-1.0$ \\
\hline Bromide & $0.5-0.9$ & \\
\hline Cadmium & $<0.001$ & $<0.001-0.005$ \\
\hline Calcium & $410-555$ & $330-445$ \\
\hline Chloride & $109-181$ & $93-110$ \\
\hline Chromium & $<0.01$ & $<0.01-0.09$ \\
\hline Cobalt & $<0.03$ & $<0.05$ \\
\hline Copper & $<0.01$ & $<0.01-0.04$ \\
\hline Fluoride & $0.4-2.2$ & $1.3-1.5$ \\
\hline Iron & $<0.03-0.2$ & $<0.03-0.13$ \\
\hline Lead & $<0.005$ & $<0.01$ \\
\hline Lead-210 (pCi/L) & $0.0-1.0$ & \\
\hline Magnesium & $44-265$ & $141-190$ \\
\hline Manganese & $<0.01-0.66$ & $0.01-0.02$ \\
\hline Mercury & $<0.0002$ & $<0.0002$ \\
\hline Molybdenum & $<0.01-0.02$ & $<0.01-0.20$ \\
\hline Nickel & $<0.04$ & $<0.04-0.11$ \\
\hline Nitrate & $<1.0-8.9$ & $0.8-11.1$ \\
\hline $\mathrm{pH}$ & $7.1-8.0$ & $7.1-7.4$ \\
\hline Phosphate & $<0.01-0.01$ & $<0.1-0.1$ \\
\hline Polonium-210 (pCi/L) & $0.5-0.7$ & 0.0 \\
\hline Potassium & $6-15$ & $5.4-8.5$ \\
\hline Radium-226 (pCi/L) & $0.0-1.5$ & $0.0-0.3$ \\
\hline Radium-228 (pCi/L) & $0.0-6.0$ & $0.0-8.5$ \\
\hline Selenium & $<0.03$ & $<0.005-0.04$ \\
\hline
\end{tabular}


Table 4.1 Background ground water quality for the Halgaito Shale and Honaker Trail Formation, Mexican Hat, Utah, site (Concluded)

\begin{tabular}{lcc}
\hline \multicolumn{1}{c}{ Constituent } & Halgaito Shale $^{\mathrm{a}}$ & Honaker Trail Formation $^{\mathrm{b}}$ \\
\hline Strontium & $10-13$ & $<0.1-9.2$ \\
Silver & $<0.01$ & $<0.01$ \\
Silica $-\mathrm{SiO}_{2}$ & $16-25$ & $14-16$ \\
Sodium & $270-740$ & $397-470$ \\
Sulfate & $2200-3300$ & $1980-2380$ \\
Sulfide & $<0.1-4.4$ & $<0.1-64.4$ \\
Thallium & $<0.03$ & \\
Thorium-230 (pCi/L) & $0-1.7$ & $0.0-0.30$ \\
Tin & $<0.05$ & $<0.005$ \\
Total dissolved solids & $3700-5300$ & $3170-3730$ \\
Total organic carbon & & $<1-31$ \\
Uranium & $0.01-0.05$ & $0.04-0.06$ \\
Vanadium & $<0.01-0.02$ & $<0.01-0.49$ \\
Zinc & $<0.005-0.01$ & $<0.01-0.03$ \\
\hline
\end{tabular}

${ }^{\mathrm{a}}$ Data are from seeps 256 (Halgaitoh Wash) and 261 (Gypsum Creek) (Figure 4.2) from 1990 to 1994.

bData were collected from monitor well 909 (Figure 4.2) from 1985 to 1993.

Note: All data are in milligrams per liter unless noted as picocuries per liter $(\mathrm{pCi} / \mathrm{L})$. Values given as less than $(<)$ are below the minimum detection limit for the analysis.

Several constituents commonly found in the solutions produced by the uranium processing at the Mexican Hat site are also present naturally in ground water from the seeps upgradient of the site. However, the concentrations of these constituents in the ground water are below those in the tailings piles.

Constituents that occur naturally in ground water from the upgradient seeps include ammonium, boron, magnesium, manganese, molybdenum, nitrate, silica, sulfate, and uranium (DOE, 1995; 1993).

\subsection{GROUND WATER MONITORING}

Most water in the Halgaito Shale was derived from uranium milling and processing activities, and to a lesser degree from transient drainage from construction of the disposal cell. The water is contained primarily in fractures within the upper portion of the Halgaito Shale and is perched on underlying zones having a lower hydraulic conductivity. Water in this unit has no current or potential use as a ground water resource because it is limited in areal extent and yield. Monitoring of water in the Halgaito Shale is not required under the current protection strategy since it is not considered a current or potential source of drinking water. 
The underlying Honaker Trail Formation contains an artesian aquifer. This aquifer is hydrogeologically isolated from the Halgaito Shale and no contamination related to the Mexican Hat processing site has been detected. Monitoring is not required for this aquifer because of the hydrogeologic isolation and the upward hydraulic gradient that has protected the aquifer from processing site-related contamination. In addition, the design of the disposal cell will minimize any additional potential for the migration of contaminants into the upper portions of the Halgaito Shale.

Due to concerns raised by the Navajo Nation, the UMTRA Ground Water Project is performing additional characterization activities within these two zones to determine whether the current hydrogeologic model is correct. The information obtained from monitoring of the seeps, as discussed in the next section, will also be used to evaluate the model. Should it be determined that the current hydrogeologic model is inaccurate, the information presented in this document will be modified.

\subsection{CELL PERFORMANCE MONITORING}

The DOE will monitor the following seeps in the disposal cell vicinity to evaluate disposal cell performance:

1. Seep 251 and in the vicinity of seep 249 in the North Arroyo. These seeps are directly north and downgradient from the disposal cell. They potentially will flow in response to precipitation runoff from the disposal cell cover, or in response to transient drainage or other anticipated discharge from the disposal cell.

2. Seeps 248,254 , and 922 . These seeps potentially could flow in response to any influx of water from the disposal cell through fractures in the Halgaito Shale to Gypsum Wash.

3. Seep 261. This seep is considered to have background-quality water. It will be monitored only if water quality sampling is required due to increased flows in the above five seeps.

The volume of flow from the seeps will be visually monitored using photographs of a baseline area to establish trends over time. The baseline area will be established using rebar to mark the current areal extent of the seeps. These measurements will be made at approximately the same time each year during the spring or summer when any potential leakage from the disposal cell would be noticeable. If measurable flow is observed at any of the seeps, an attempt will be made to quantify the magnitude of flow. The procedure for measurement and reporting will be determined by the technical inspector at the time. Water in the seeps is expected to decrease in time and return to natural conditions.

If a sufficient volume of water can be collected from the seeps, it will be sampled and analyzed for uranium, sulfate, and nitrate. If analysis of the 
indicator parameters indicates a degradation of seepage water quality, then additional sampling and analysis will be performed. The constituents of potential concern to be analyzed include ammonium, calcium, chloride, molybdenum, nitrate, potassium, radium-226 and -228 , sodium, sulfate, total dissolved solids, uranium, and vanadium. The results of the sampling would be evaluated to determine whether degradation was indicative of disposal cell failure. Rainfall records will also be reviewed for potential increases in fracture recharge caused by runoff into and infiltration from the north apron and drains. As appropriate, other follow-up assessment activities may be conducted, such as comparing past cell and apron inspections to current inspections.

Indications of cell failure, if any, will be responded to. Seeps could be monitored more frequently. In addition, sampling the San Juan River at its confluence with Gypsum Wash could be added to the monitoring program. 


\subsection{CUSTODIAL MAINTENANCE AND REPAIR}

Custodial maintenance or repair will be performed as needed at the Mexican Hat disposal site. In general, the decision to conduct maintenance or repair will be based on the results of scheduled site inspections, follow-up inspections, or contingency inspections.

\subsection{PLANNED MAINTENANCE}

Planned maintenance at the Mexican Hat disposal site will be limited to a spraying program to control unwanted vegetation growth on the disposal cell. Due to the arid conditions at the site and the sporadic frequency and amount of rainfall, this spraying will be done as needed. Vegetation growth will be monitored during regularly scheduled inspections conducted during the growing season. If significant vegetation is found, a maintenance visit to apply herbicidal spray or to implement mechanical removal techniques will be scheduled.

\subsection{UNSCHEDULED MAINTENANCE OR REPAIR}

Unscheduled custodial maintenance or repair activities that may be required at the Mexican Hat disposal site include the following:

- Repair of entrance gate and fencing.

- Replacement of entrance and perimeter signs.

- Reestablishment of survey and boundary monuments, site markers, and settlement plates.

- Eradication of deep-rooted trees and shrubs.

- Removal of tumbleweeds or other debris from the drainage and diversion ditches and armored gullies or from around the disposal site fence.

- Control of burrowing animals.

- Placement of fill in gullies or rills.

- Replacement of rock erosion-protection materials.

After maintenance is completed and before contractors are released, the DOE will verify that work was performed according to the statement of work. The annual report to the NRC and Navajo Nation will document any repair that is performed. Copies of all records, reports, and certifications will be included in the permanent site file. 


\subsection{CORRECTIVE ACTION}

Corrective action is the repair needed to address problems that affect the integrity of the disposal cell. Problems will be reported to the NRC and the Navajo Nation. The NRC must approve the recommended action in advance. Site inspections and ground water monitoring are designed to identify problems at the developmental stage. Examples of conditions that might trigger corrective action are as follows:

- Surface rupture or subsidence of the disposal cell.

- Development of rills or gullies or slope instability on the disposal cell.

- Deterioration of the erosion-protection rock on the disposal cell.

- Tailings fluids originating from the disposal cell.

- Gully development on or immediately adjacent to disposal site property that could affect the integrity of the disposal cell.

- Damage to the cell cover or disposal site property from natural catastrophic events or vandalism.

- Damage to the disposal cell cover from deep-rooted plant growth.

- Verification of cell failure after evaluation of the cause of significant seepage flow increases resulting from cell performance monitoring.

If conditions such as these are observed during an annual inspection, a follow-up inspection will be conducted. The DOE will evaluate the factors that caused the problem and identify actions to mitigate the impact and prevent recurrence by:

- Identifying the nature and extent of the problem.

- Reevaluating germane engineering design parameters.

The DOE will submit a preliminary assessment report to the NRC and Navajo Nation for review no more than 60 days after a problem is identified. The preliminary assessment report will evaluate the problem and recommend the next step (e.g., immediate action or continued evaluation). If the problem requires immediate repair, the DOE will develop a corrective action plan for NRC approval. Once the NRC approves the corrective action, the DOE will implement the plan. In some cases, corrective action could include temporary emergency measures taken before completion of the normal approval process. If a problem does not require immediate repair, the problem will be documented in the annual report and assessed at the next annual inspection.

NRC regulations do not stipulate a time frame for implementing corrective action. However, 40 CFR $\$ 192.04$ requires that a corrective action program begin within 18 months after a finding of an exceedance in established ground water concentration limits. 
The DOE does not consider assessing the extent of a problem and developing a corrective action plan to be initiation of the corrective action program.

In addition to the preliminary assessment report, the DOE may, as appropriate, prepare progress reports on each corrective action while it is under way or under evaluation.

After corrective action is complete, the DOE will certify all work and submit a certification statement and supporting documentation to the NRC and Navajo Nation for review and concurrence. A copy of the certification statement will become part of the permanent site file, as will all reports, data, and documentation generated during the corrective action. 


\subsection{RECORD KEEPING AND REPORTING}

\subsection{PERMANENT SITE FILE}

The DOE will maintain a permanent site file containing site inspection reports and other supporting documentation of long-term surveillance program activities. The information placed in the site file will include:

- Documentation of disposal site performance (inspection/ground water monitoring).

- Demonstration that licensing provisions were met.

- Information needed to forecast future site surveillance and monitoring needs.

- Reports to stakeholders regarding disposal cell integrity.

After the site is brought under the general license, the DOE will compile copies of site documentation required by the long-term surveillance program guidance (DOE, 1996a) for the Mexican Hat disposal site permanent site file. Copies of all deeds, custody agreements, and other property documents will be kept in the site file.

The surveillance and maintenance documentation identified in other sections of this LTSP will be maintained by the DOE and become part of the permanent site file. The DOE will update the site file as necessary after disposal site inspections, maintenance activities, or corrective actions are complete. These records will be handled in accordance with DOE directives to ensure their proper handling, maintenance, and disposition. The archival procedures set forth in 41 CFR Part 101 and 36 CFR Parts 1220-1238, Subchapter B, will be followed. Information in the site file will be available for NRC and public review.

\subsection{INSPECTION REPORTS/ANNUAL REPORTS}

During site inspections, activities and observations will be recorded and described using site inspection checklists, maps, photographs and photo logs, and field notes.

Documentary evidence of anomalous, new, or unexpected conditions or situations must describe developing trends and enable the DOE to make decisions concerning follow-up inspections, custodial maintenance, and corrective action. This information will be contained in the permanent site file at the DOE office. The DOE will prepare a site inspection report documenting the findings and recommendations from each field inspection.

Site inspection reports will be submitted to the NRC and the Navajo Nation within 90 days of the annual site inspection. Inspection reports will summarize the results of follow-up inspections and maintenance completed since the previous annual inspection.

If unusual damage or disruption is discovered at the Mexican Hat disposal site during an inspection, a preliminary report assessing the impact must be submitted to the NRC and Navajo Nation within 60 days. If maintenance, repair, or corrective action is warranted, the DOE will notify the NRC and Navajo Nation. The NRC and Navajo Nation will receive a copy of corrective action plans and each corrective action progress report, or the reports will be attached to the annual report. 
The DOE will provide copies of inspection reports and other reports generated under the long-term surveillance program to the Navajo Nation as required in their cooperative agreement. 


\subsection{QUALITY ASSURANCE}

\subsection{INSPECTIONS}

The DOE has developed and implemented a quality assurance (QA) plan (DOE, 1996b) for the site inspection program that meets the requirements of DOE Order 5700.6C. Site inspections will be conducted in accordance with this plan.

\subsection{DATA VALIDATION AND QUALITY ASSURANCE}

All aspects of the ground water monitoring plan will be in accordance with accepted EPA and industry QA practices, including DOE directives in DOE Order 5700.6C. 


\subsection{REFERENCES}

DOE (U.S. Department of Energy), 1996a. Guidance for Implementing the Long-Term Surveillance Program for UMTRA Project Title / Disposal Sites, DOE/AL-62350-189, Rev. 0, prepared for the U.S. Department of Energy, Environmental Restoration Division, UMTRA Project Team, Albuquerque, New Mexico.

DOE (U.S. Department of Energy), 1996b. Long-Term Surveillance and Maintenance Program, Quality Assurance Program Plan, MAC-2152, Rev. 0, prepared by MACTEC Environmental Restoration Services for the U.S. Department of Energy, Grand Junction Office, Grand Junction, Colorado.

DOE (U.S. Department of Energy), 1995. UMTRA Project Site Observational Work Plan, Mexican Hat, Utah, DOE/AL/62350-153, Rev. O, DOE UMTRA Project Office, Albuquerque Operations Office, Albuquerque, New Mexico.

DOE (U.S. Department of Energy), 1994. UMTRA Project Water Sampling and Analysis Plan, Mexican Hat, Utah, DOE/AL/62350-118, DOE UMTRA Project Office, Albuquerque Operations Office, Albuquerque, New Mexico.

DOE (U.S. Department of Energy), 1993. Remedial Action Plan for the Codisposal and Stabilization of the Monument Valley and Mexican Hat Uranium Mill Tailings at Mexican Hat, Utah, UMTRA-DOE/AL-050509.0000, DOE UMTRA Project Office, Albuquerque Operations Office, Albuquerque, New Mexico.

DOE (U.S. Department of Energy), 1990. Assessment of Seeps in the Vicinity of the Mexican Hat Tailings Disposal Cell, October 1990, prepared by the U.S. Department of Energy, UMTRA Project Office, Albuquerque Operations Office, Albuquerque, New Mexico.

DOE (U.S. Department of Energy), 1989. Environmental Assessment of Remedial Action at the Monument Valley Uranium Mill Tailings Site, Monument Valley, Arizona, DOE/EA-0368, U.S. DOE, UMTRA Project Office, Albuquerque Operations Office, Albuquerque, New Mexico.

DOE (U.S. Department of Energy), 1987. Environmental Assessment, Remedial Action at the Mexican Hat Uranium Mill Tailings Site, Mexican Hat, Utah, DOE/EA-0332, U.S. DOE UMTRA Project Office, Albuquerque Operations Office, Albuquerque, New Mexico.

FBDU (Ford, Bacon and Davis Utah, Inc.), 1981. Engineering Assessment of Inactive Uranium Mill Tailings, Mexican Hat Site, Mexican Hat, Utah, DOE/UMT-0109, FBDU 360-03, UC 70, prepared by Ford, Bacon and Davis Utah, Inc., for the U.S. Department of Energy, UMTRA Project Office, Albuquerque Operations Office, Albuquerque, New Mexico. 
MK (Morrison Knudsen Corporation), 1992. UMTRA Project Mexican Hat and Monument Valley Sites, Engineering Geology Report, prepared by Morrison Knudsen Corporation, Environmental Services Division, San Francisco, California.

MK-F (MK-Ferguson Company), 1995. "Mexican Hat, Utah, Monument Valley Arizona, Draft Completion Report," prepared by MK-Ferguson Company for the U.S. Department of Energy, UMTRA Project Team, Environmental Restoration Division, Albuquerque, New Mexico.

NRC (U.S. Nuclear Regulatory Commission), 1996. “Final Technical Evaluation Report for the Remedial Action of the Monument Valley, Arizona, and Mexican Hat Tailings Site, Mexican Hat, Utah, Uranium Mill Tailings Sites," Division of Low-Level Waste Management and Decommissioning, Office of Nuclear Material Safety and Safeguards, Washington, D.C.

Snelling, R. N, 1971. "Environmental Survey of the Uranium Mill Tailings Pile, Mexican Hat, Utah," Radiological Health Data Reports, Vol. 12, Southwestern Radiological Health Laboratory, Bureau of Radiological Health, Las Vegas, Nevada.

\section{CODE OF FEDERAL REGULATIONS}

10 CFR Part 40, Domestic Licensing of Source Material, U.S. Nuclear Regulatory Commission.

36 CFR Parts 1220-1238, National Archives and Records, Subchapter B - Records Management, National Archives and Records Administration.

40 CFR Part 192, Health and Environmental Protection Standards for Uranium and Thorium Mill Tailings, U.S. Environmental Protection Agency.

41 CFR Part 101, Federal Property Management Regulations, General Services Administration.

\section{DOE ORDERS}

Order 5700.6C, Quality Assurance, 21 August 1991, Office of Nuclear Energy and Office of Environment, Safety, and Health, U.S. Department of Energy, Washington, D.C. 


\section{ATTACHMENT 1}

NRC CONCURRENCE AND LICENSING DOCUMENTATION 
NRC concurrence and licensing documentation will be included when the site is licensed. 
ATTACHMENT 2

LEGAL DESCRIPTION 


\section{LEGAL DESCRIPTION}

Remedial action at the Mexican Hat UMTRA site consisted of consolidation and stabilization of the contaminated materials on-site. Remedial action also included the relocation of contaminated materials at the Monument Valley, Arizona, site to the Mexican Hat site. Under the requirements of the Uranium Mill Tailings Radiation Control Act (UMTRCA) of 1978, as amended, and under the terms of the Cooperative Agreement between the Navajo Nation and the federal government, the Navajo Nation and the DOE participated in the selection and performance of remedial action at the two designated sites through completion.

The Mexican Hat designated processing site consisted of approximately 235 acres. The acreage of the final disposal site consists of approximately 119 acres.

\section{Transfer of the final Disposal Site}

The DOE and the Navajo Nation executed a Custodial Access Agreement (CAA) titled "Transfer of Custody of the Uranium Mill Tailings Disposal Cells and Right of Access to the Uranium Mill Tailings Disposal Sites Located on the Navajo Nation." The CAA conveys to the federal government title to the residual radioactive materials stabilized at the repository site. The UMTRCA authorized the DOE to enter into Cooperative Agreement DE-FC04-85AL26731 with the Navajo Nation. The purpose was to perform remedial actions at the former processing sites designated by the Secretary of Energy pursuant to UMTRCA at Shiprock, New Mexico; Monument Valley, Arizona; Mexican Hat, Utah; and Tuba City, Arizona. The U.S. Nuclear Regulatory Commission also required such an agreement prior to bringing the sites under the general license in Title 10 of the Code of Federal Regulations 10 CFR \$40.27.

The CAA ensures that the DOE has perpetual access to the respective sites and grants the DOE custody of the residual radioactive materials, cover components, and engineered features (including, but not limited to drainage ditches, erosion control markers, fencing, boundary markers, and monitor wells).

The effective date of the CAA is August 12, 1996, having been executed by the DOE's Contracting Officer, Juan Williams, the Navajo Nation President, Albert Hale, and the Bureau of Indian Affairs Area Director, Wilson Barber, Jr.

\section{LEGAL DESCRIPTION}

A tract or parcel of land located in the Navajo Reservation described as follows: Beginning point is reached by moving South 6817.30 feet and West 4247.41 feet from the NE corner of Section 7, Township 42 South, Range 19 East, Salt Lake Base and Meridian to Station 1 and thence S28 $44^{\prime} 53^{\prime \prime} \mathrm{W} 798.41$ feet to the point of beginning. From the point of beginning move: 
$S 38^{\circ} 12^{\prime} 22^{\prime \prime}$ E591.76 feet, thence

$S 03^{\circ} 34^{\prime} 35^{\prime \prime}$ W545.06 feet, thence

S $29^{\circ} 54^{\prime}$ 00" W960.90 feet, thence

$S 71^{\circ} 26^{\prime} 45^{\prime \prime}$ W1671.90 feet, thence

N $87^{\circ} 06^{\prime} 49^{\prime \prime}$ W238.30 feet, thence

$N 51^{\circ} 18^{\prime} 40^{\prime \prime}$ W617.51 feet, thence

$N 19^{\circ} 04^{\prime} 19^{\prime \prime}$ E483.54 feet, thence

$\mathrm{N} 01^{\circ} 17^{\prime} 32^{\prime \prime} \mathrm{E} 1064.27$ feet, thence

$N 62^{\circ} 55^{\prime} 49^{\prime \prime}$ E914.14 feet, thence

$N 81^{\circ} 01^{\prime} 39^{\prime \prime} E 288.53$ feet, thence

$N 58^{\circ} 01^{\prime} 52^{\prime \prime}$ E332.42 feet, thence

$S 78^{\circ} 25^{\prime} 48^{\prime \prime} \mathrm{E} 907.44$ feet, to the point of beginning containing 118.798 acres. 


\section{ATTACHMENT 3}

\section{AGENCY NOTIFICATION AGREEMENTS}




\section{DISCLAIMER}

This report was prepared as an account of work sponsored by an agency of the United States Government. Neither the United States Government nor any agency thereof, nor any of their employees, makes any warranty, express or implied, or assumes any legal liability or responsibility for the accuracy, completeness, or usefulness of any information, apparatus, product, or process disclosed, or represents that its use would not infringe privately owned rights. Reference herein to any specific commercial product, process, or service by trade name, trademark, manufacturer, or otherwise does not necessarily constitute or imply its endorsement, recommendation, or favoring by the United States Government or any agency thereof. The views and opinions of authors expressed herein do not necessarily state or reflect those of the United States Government or any agency thereof. 


\section{Department of Energy \\ Albuquerque Operations Office \\ P.O. Box 5400 \\ Albuquerque, New Mexico 87185-5400}

June 12, 1997

Mr. Mike Lacy

San Juan County Sheriff's Department

P.O. Box 788

Monticello, UT 84535

Dear Mr. Lacy:

The U.S. Department of Energy (DOE) is requesting notification in the event of any unusual activities or events occurring in San Juan County, Utah, associated with the Mexican Hat disposal site. The purpose of the notification request is to assist the DOE in monitoring and maintaining the integrity of its disposal site.

If anything out of the ordinary associated with the disposal site is observed by your staff or reported to your office, we would appreciate notification to the DOE Grand Junction Office 24-hour phone at (970)248-6070. If the notification request discussed above is agreeable to you, please sign this letter and return it in the envelope provided.

Thank you for your attention in this matter. Give me a call at (505)845-5668 if you have any questions.

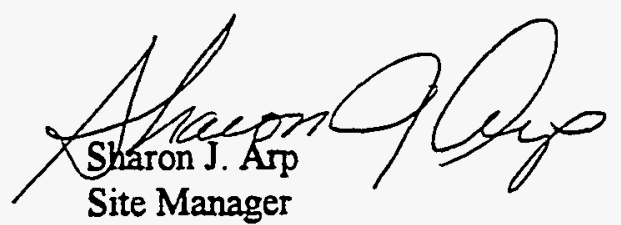

Site Manager

Uranium Mill Tailings Remedial Action Team

Environmental Restoration Division

cc:

J. McBee, TAC

J. Virgona, GJO

The San Juan County Sheriff s office agrees to contact the DOE Grand Junction Office 24-hour phone at (970) 248-6070 if any unusual event or anomaly is observed or reported at the Mexican Hat disposal site, Mexican Hat, Utah.

Mike Lacy

Date

San Juan County Sheriff 


\section{Department of Energy \\ Albuquerque Operations Office \\ P.O. Box 5400}

Albuquerque, New Mexico $87185-5400$

June 12, 1997

Mr. Kee Thinn

District Commander

Navajo Police Department

P.O. Box Drawer 22

Kayenta, AZ 86033

Dear Mr. Thinn:

The U.S. Department of Energy (DOE) is requesting notification in the event of any unusual activities or events occurring in San Juan County, Utah, associated with the Mexican Hat disposal site. The purpose of the notification request is to assist the DOE in monitoring and maintaining the integrity of its disposal site.

If anything out of the ordinary associated with the disposal site is observed by your staff or reported to your office, we would appreciate notification to the DOE Grand Junction Office 24-hour phone at (970)248-6070. If the notification request discussed above is agreeable to you, please sign this letter and return it in the envelope provided.

Thank you for your attention in this matter. Give me a call at (505)845-5668 if you have any questions.

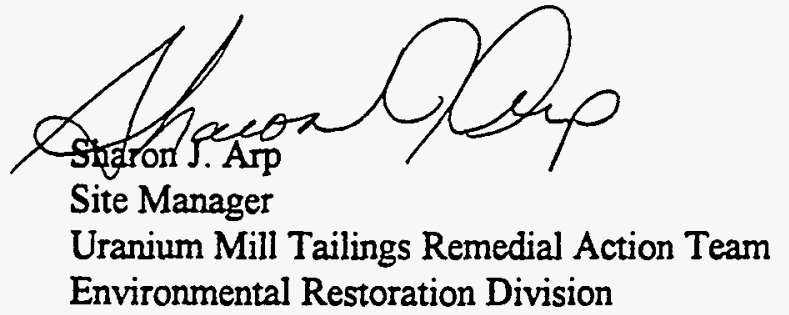

cc:

J. McBee, TAC

J. Virgona, GJO

The Navajo Police Department agrees to contact the DOE Grand Junction Office 24-hour phone at (970) 248-6070 if any unusual event or anomaly is observed or reported at the Mexican Hat disposal site, Mexican Hat, Utah.

Kee Thinn

Date

Navajo Police Department 


\section{National Earthquake Information Center}

World Data Center A for Seismology

Director
(303) 236-1510
Research
(303) 236-1506

\author{
C.S. Geological Survey \\ Box 25046. DFC. MS.96T \\ Dequer. Colorado 80205 LSA
}

Telex: (KTTCO) 510601\$123ESL [DD
Operations

(303) 236-1500

QED

(800) 358.2663

Clinton C. Smythe

Engineering and Construction Group Leader

Uranium Mill Tailings Remedial Action

Project Office

2155 Louisiana NE, Suite 4,000

Albuquerque, NM 87110

Dear Mir. Smythe:

This letter is to confirm that the DOE Grand Junction Projects Office (24-hour phone line, (303) 248-6070 has been added to our notification list for the occurrence of earthquakes near the following locations:

\begin{tabular}{|l|l|l|}
\hline Disposal Site & Latitude & Longitude \\
\hline COLORADO & & \\
\hline Durango (Bodo Canyon) & N37.15 & W107.90 \\
\hline Grand Junction & N38.91 & W108.32 \\
\hline Gunnison (Landtill) & N38.51 & W106.85 \\
\hline Maybell & N40.55 & W107.99 \\
\hline Naturita (Dry Flats) & N38.21 & W108.60 \\
\hline Rifle (Estes Gulch) & N39.60 & W107.82 \\
\hline Slick Rock (Burro Canyon) & N38.05 & W108.87 \\
\hline IDAHO & & \\
\hline Lowman & N44.16 & W115.61 \\
\hline NEW MEXICO & & \\
\hline Ambrosia Lake & N35.41 & W107.80 \\
\hline NDRTHDAKOTA & & \\
\hline Bowman & N46.23 & W103.55 \\
\hline OREGON & & \\
\hline Lakeview (Collins Ranch) & N42.2 & W120.3 \\
\hline PENNSYLVANIA & & \\
\hline Canonsburg & N40.26 & W80.25 \\
\hline Burell VP & N40.62 & W79.65 \\
\hline TEXAS & & \\
\hline Falls City & N28.91 & W98.13 \\
\hline UTAH & & \\
\hline Mexican Hat & N37.10 & W109.85 \\
\hline Salt Lake City (Clive) & N40.69 & W113.11 \\
\hline
\end{tabular}




\section{National Earthquake Information Center.}

\section{World Data Center A for Seismology}

Director

(303) 236-1510

Research

(303) 236-1506
U.S. Geologieal Survey

Box 25046, DFC. MS-957

Denver, Colorado 80225 USA

Telex: (WTTCO) 5105014123ESL CD
Operations

(303) 236-1500

QED

(800) $358-2663$

Clinton C. Smythe

$-2-$

We have entered the following selection criteria into our notification program:

1. Any earthquake of magnitude 3.0 or greater, within 0.3 degrees (about 20 miles) of any site shown above, or

2. Any earthquake of magnitude 5.0 or greater, within 1.0 degrees (about 70 miles) of any site shown above.

Sincerely,

Buce wo. Preageare

Earice Presgrave

U.S. Geological Survey

National Earthquake Information Center

P.O. Box 25046

Mail Stop 967

Denver Federal Center

Denver, Colorado 80225

Piease add'ress future comespondorree to Stuert Koyanegi at thie abore address. I have moved to a different project.

Thank you t bert regards,

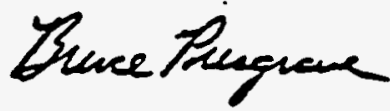




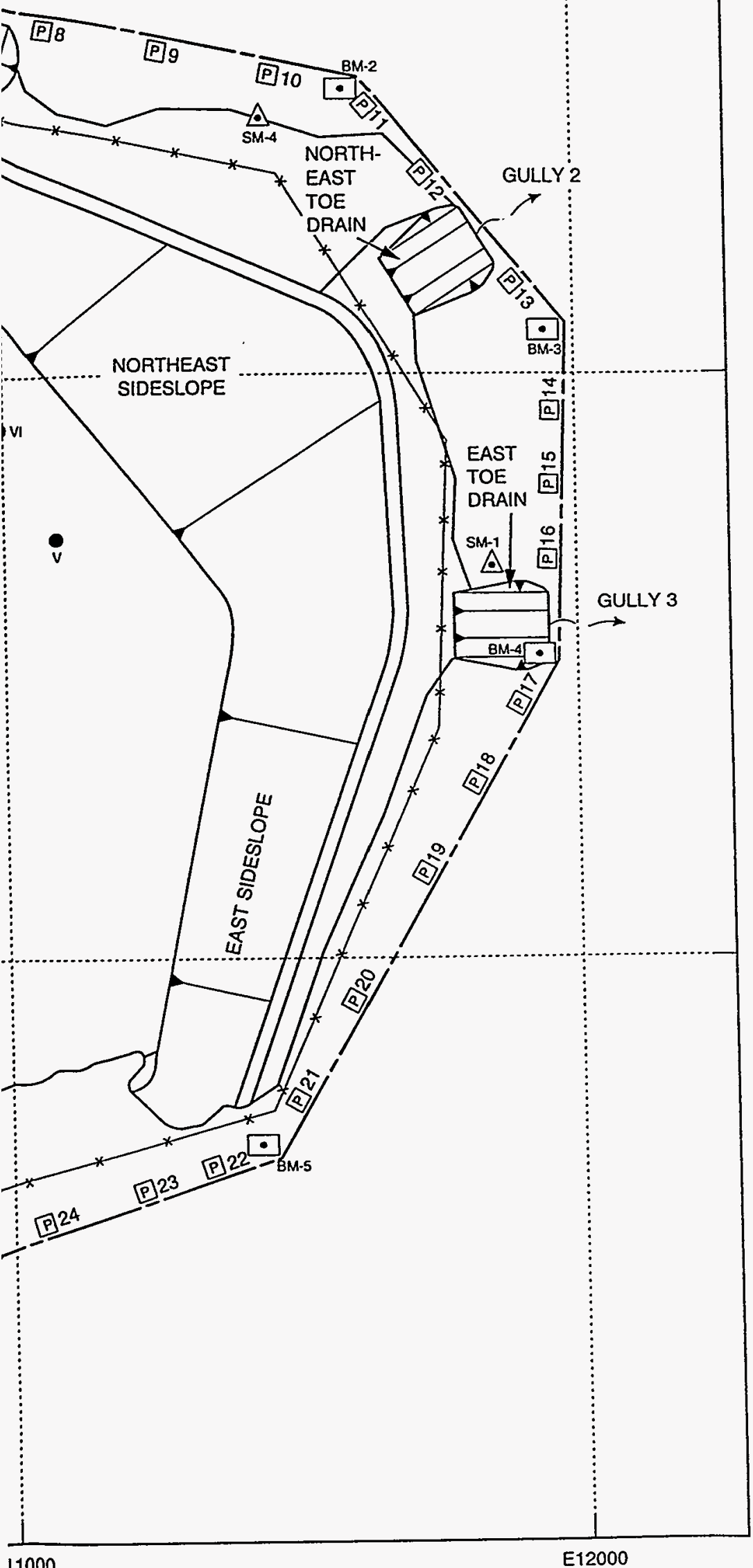

\section{LEGEND}

$\triangle$ PERMANENT SURVEY MONUMENT

- PERMANENT BOUNDARY MONUMENT

[0 GRANITE SITE MARKER

- SeTtLEMENT PLATE

D30 PERIMETER SIGN AND REFERENCE NUMBER

[] ENTRANCE SIGN

D. CHAIN LINK FENCE AND 20 FT WIDE DOUBLE LEAF SWING GATE

* * BARBED WIRE FENCE

IT EMBANKMENT SHOWING DIRECTION OF SLOPE

- - SITE BOUNDARY

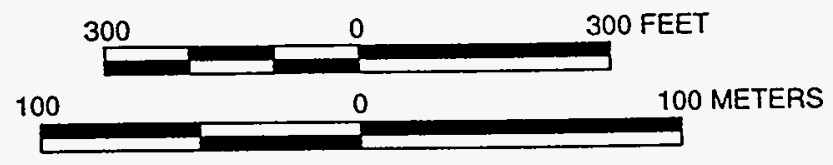

REF: DOE, 1995.

PLATE 1

DISPOSAL SITE MAP MEXICAN HAT, UTAH 


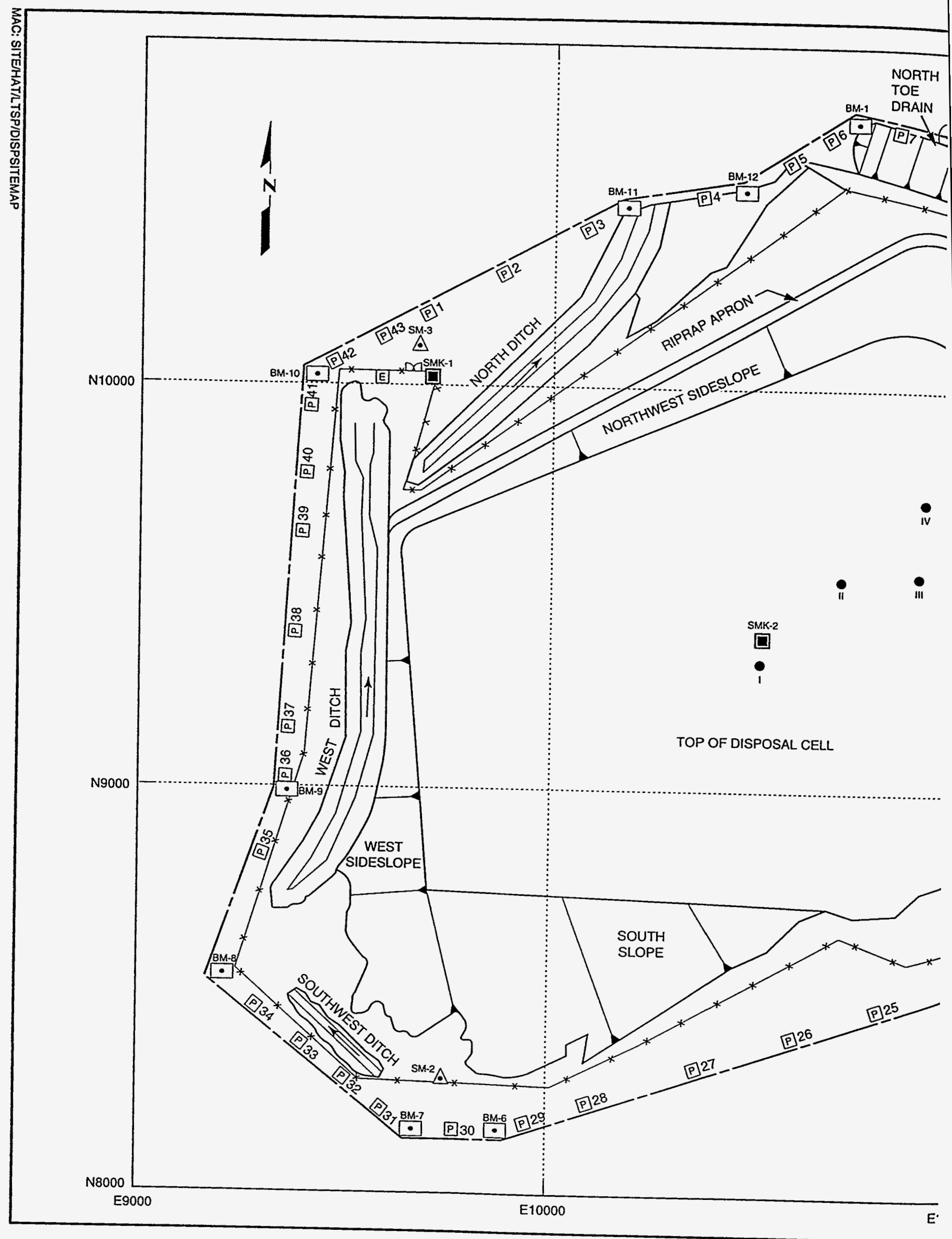

